УДК 347.962

DOI https://doi.org/10.32849/2663-5313/2019.6.62

\title{
Ганна Вітюк,
}

асистент кафедри організаиії судових,

правоохоронних органів та адвокатури

Національного університету «Одеська юридична академія»

\section{ЕТИЧНІ ОСНОВИ СУДДІВСЬКОЇ ДІЯЛЬНОСТІ ТА ОСОБЛИВОСТІ ЇХ МІЖНАРОДНО-ПРАВОВОЇ РЕГЛАМЕНТАЦІї}

У статті досліджуються та аналізуються тексти основних міжнародно-правових актів, що регламентують діяльність судді. Описуються міжнародні та європейські стандарти професійної етики судді та шляхи їх імплементаиії в наиіональне законодавство. Доводиться необхідність дотримання суддями етичних засад суддівської діяльності як основи формування довіри громадськості до судової влади.

Ключові слова: міжнародно-правові стандарти, суддя, судова етика, етика судді, Бангалорські принципи, довіра до судової влади.

Постановка проблеми. У зв'язку з післявоєнними (мається на увазі Друга світова війна) демократичними трансформаціями у Свропі, великого поширення набули також нові підходи до регламентації судової діяльності та її організаційного аспекту. Так, існує ціла низка міжнародних нормативноправових актів, які стосуються цього питання: Основні принципи щодо незалежності правосуддя, схвалені резолюціями 40/32 та 40/146 Генеральної Асамблеї ООН від 29 листопада та 13 грудня 1985 року; Бангалорські принципи поведінки суддів, схвалені резолюцією 2006/23 Економічної і Соціальної Ради ООН від 27 липня 2006 року; Свропейська Хартія про статус суддів, прийнята багатосторонньою нарадою 10 липня 1998 року; чотири Рекомендації Комітету Міністрів Ради Європи 1981-го, 1986-го, 2004-го та 2010-го років та понад десяток Висновків Консультативної ради європейських суддів. Особливого значення для дослідження саме професійно-етичного складника діяльності суддів мають два головних міжнародних акти - Бангалорські принципи поведінки суддів та Висновок № 3 (2002) Консультативної ради європейських суддів до уваги Комітету Міністрів Ради Європи щодо принципів та правил, які регулюють професійну поведінку суддів, зокрема питання етики, несумісної поведінки та безсторонності.

Із часів незалежності проблеми суддівської етики та відповідальності за іï порушення все частіше висвітлюються у фахових юридичних виданнях та навчальній літературі українськими дослідниками, серед яких В. Городовенко, Ю. Меліхова, О. Овчаренко,
О. Піджаренко, С. Прилуцький, Д. Притика, I. Самсін, В. Фролов та ін. [1; 4; 5; 7 та ін.]. Однак самі стандарти суддівської етики, викладені у міжнародних та національних актах, особливості їхньої юридичної сили та ступінь обов'язковості, а також негативні наслідки їх порушення залишаються не досить відомими представникам професійної громадськості. Усе це вказує на необхідність дослідження проблеми на рівні загальнотеоретичного дослідження.

|| Метою статті є дослідження норм основних міжнародно-правових актів, що регламентують діяльність судді, а особливо в частині дотримання ним етичних засад суддівської діяльності.

Виклад основного матеріалу. Бангалорські принципи поведінки суддів являють собою документ, схвалений резолюцією 2006/23 Економічної і Соціальної Ради ООН від 27 липня 2006 року, що складається 3 преамбули, окремих розділів, кожен з яких пов'язаний 3 тлумаченням певного принципу, положення про введення в дію і визначення вживаних у документі термінів.

Що стосується преамбули, то вона цікава насамперед 3 огляду на наявні в ній положення, які вказують на взаємозалежність між довірою до суду, правопорядком загалом та дотриманням суддями тих рекомендацій, які викладені в цьому документі. Також заслуговує на окрему увагу вказівка на те, що заохочення та підтримання високих стандартів поведінки суддів є безпосереднім обов'язком судових органів кожної держави [6]. Слід наголосити, що самі Бангалорські принципи 
поведінки суддів не дають чіткого визначення, у якій саме формі повинно відбуватися таке заохочення та підтримання, i, як наслідок, такий механізм відсутній і в національному законодавстві.

Перший показник, на який звертається увага в описуваному документі - незалежність. Цей принцип з позиції поведінки суддів трактується так: «незалежність судових органів є передумовою забезпечення правопорядку та основною гарантією справедливого вирішення справи в суді. Отже, суддя має відстоювати та втілювати в життя принцип незалежності судових органів у його індивідуальному та колективному аспектах». Тут, ймовірно, індивідуальний аспект слід розуміти в значенні незалежності конкретно взятого судді, а колективний - стосовно суддівського корпусу загалом.

Застосування цього принципу пропонується таке. «Суддя повинен здійснювати свою судову функцію незалежно, виходячи виключно 3 оцінки фактів, відповідно до свідомого розуміння права, незалежно від стороннього впливу, спонукання, тиску, погроз чи втручання, прямого чи опосередкованого, що здійснюється 3 будь-чийого боку та з будь-якою метою». Після цього йде вказівка на те, що суддя повинен дотримуватися незалежної позиції по відношенню до суспільства загалом та окремо до кожного учасника справи. Вартим особливої уваги є п.1.3 першого принципу, оскільки в ньому йдеться про те, що суддя повинен уникати міжвідомчих та інших невідповідних відносин не лише з метою забезпечення виконання принципу незалежності, а і так, щоб це не викликало сумнівів у його незалежності для стороннього спостерігача. Це положення грунтується на тому, що судді, як правило, здійснюють свою діяльність протягом тривалого проміжку часу i, як наслідок, з часом «обростають» вимушеними нейтральними чи дружніми стосунками з іншими частими учасниками судових засідань - прокурорами, адвокатами тощо. 3 огляду на такий стан речей, вираження таких стосунків повинне піддаватися певним обмеженням, оскільки якщо для працівників суду бесіда судді 3 прокурором поза межами засідання є звичайним явищем, то для стороннього спостерігача вона може слугувати фактором, що може спричинити сумнів у незалежності конкретно взятого судді. Особливо гостро ця проблема відчувається у тих судах, які функціонують у невеликих населених пунктах, оскільки з об'єктивних причин абсолютне виконання там цього припису $є$ неможливим (там просто немає «сторонніх спостерігачів»). Як наслідок, саме такі суди можна віднести в зону ризику з точки зору дотримання їх суддями правил професійної етики: у колі «своїх» вони можуть природно віддалитися від необхідності дотримання певних рамок.

Другий принцип стосується об'єктивності суддів та визначає її «необхідною умовою для належного виконання ними своїх обов'язків. Вона проявляється не тільки у змісті винесеного рішення, а й в усіх процесуальних діях, що супроводжують його прийняття». Відповідно до цього принципу суддя, виконуючи свої обов'язки, повинен бути вільним від будь-яких схильностей, упередженості чи забобонів (що не перешкоджає їх існуванню поза судовим процесом). Це застереження є дуже важливим 3 огляду на те, що суддям загалом властиві прояви професійної деформації, як, наприклад, формування про обвинуваченого чи підозрюваного думки, відповідно до якої він стає винним ще задовго до винесення відповідного вироку. Саме на боротьбу з такими проявами професійної деформації спрямований в тому числі і вищевказаний принцип об'єктивності суддівської діяльності.

Крім уже вказаного, принцип об'єктивності суддівської діяльності повинен виражатися не лише у межах судового засідання, а поза стінами суду - недопустимими визначаються такі вчинки судді, які можуть викликати сумнів у його об'єктивності. Звідси випливає та закріплюється у наступних підпунктах цього документа те, що судді повинні взагалі обмежуватися від публічних оціночних суджень, що можуть викликати сумнів у їх неупередженості, адже суддя, який публічно висловився на користь, наприклад, криміналізації сімейного насильства, не зможе бути об'єктивним у вирішенні справи про таке адміністративне правопорушення (для суспільства після публічного висловлювання щодо свого ставлення до сімейного насильства він вже виступає як особа, яка оцінює його скоріше більш жорстко, ніж законодавець, а отже - не об'єктивно). Тут же можемо зустріти вказівку на те, що судді загалом повинні уникати тих ситуацій, які можуть в майбутньому слугувати підставою для заявлення ними самовідводу.

Значно менш розгорнуто за інші представлений в Бангалорських принципах поведінки суддів третій показник їхньої діяльності: «чесність та непідкупність є необхідними умовами для належного виконання суддею своїх обов'язків». Як пропозицію у застосуванні цього принципу слушно сказано про необхідність для суддів не просто чинити правосуддя, а й намагання робити це відкрито для суспільства. Будь-які прояви обме- 


\section{6/2019 судоустРІй}

ження розумного доступу до певної інформації учасників провадження (наприклад, потерпілого - до матеріалів провадження) може піддати сумніву чесність судді.

Четвертим показником, який описаний в Бангалорських принципах поведінки суддів, є принцип дотримання ними етичних норм. Цікавим $є$ те, що, по суті, всі перелічені в документі принципи стосуються тією чи іншою мірою дотримання етичних норм, і даний пункт пропонує своєрідну альтернативу розуміння моральної відповідальності судді перед суспільством. Так, пропонується таке визначення цього принципу: «дотримання етичних норм, демонстрація дотримання етичних норм є невід'ємною частиною діяльності суддів». Пропозиції щодо застосування цього правила в документі висвітлені досить широко та включають в себе не лише зобов'язання, а й перелік відповідних прав. Так, вказано, що суддям, як і всім іншим громадянам, забезпечено право на висловлення своїх думок чи поглядів, але суддям необхідно дотримуватися обережності у реалізації такого права із розумінням своєї серйозної ролі в суспільстві. Тут же йдеться про те, що такі етичні обмеження можуть для стороннього спостерігача здатися надмірними, проте суддя добровільно приймає ці обмеження і повинен робити це охоче - інакше, з точки зору автора, кандидату на цю важливу посаду слід звернутися до не пов'язаних із правосуддям способів самореалізації.

Особливу увагу у застосуванні описуваного принципу приділено питанню неетичних зловживань суддями своїм статусом: суддя не має права використовувати чи дозволяти використовувати авторитет власної посади для досягнення особистих інтересів, інтересів членів своєї сім'ї чи інших осіб. Це свідчить про те, що зловживання такого характеру, попри поширену в суспільстві думку, характерні не лише для України, а i для зразкових західних демократій. Важливим визначається також недопущення суддями розголошення інформації, що стала ім доступна внаслідок здійснення безпосередніх повноважень. Тут помітна схожість цього принципу 3 лікарською таємницею, чим лише підкреслюється його важливість. Слід розуміти, що розголошення отриманої в судовому засіданні інформації може лише до певного моменту вважатися просто небажаною з точки зору етики поведінкою, якщо йдеться, наприклад, про згвалтування, то розголошення третім особам деталей вчинення цього злочину може стати особистою трагедією окремої людини.

П'ятим принципом поведінки суддів у аналізованому документі є рівність. Опи- суючи його, автор документа вказує на необхідність рівнозначної оцінки суддею під час здійснення правосуддя тих особистісних факторів людей, які «не стосуються справи»: расової приналежності, кольору шкіри, статі, релігії, національного походження, касти, непрацездатності, віку, сімейного стану, сексуальної орієнтації, соціально-економічного стану тощо. Якщо звернутися до соціальних досліджень, то побачимо, що суспільство вказує на порушення суддями принципу рівності: на думку українців, у громадянина 3 високим рівнем доходів, у роботодавця, у представника органу влади значно більші шанси на вирішення спору на їх користь порівняно з шансами громадянина 3 низьким рівнем доходів, найманого працівника та звичайного громадянина відповідно [2]. Це одночасно є причиною та ілюстрацією низького рівня довіри до суду в Україні, що, безумовно, шкодить розбудові правової держави.

В останню чергу в Бангалорських принципах поведінки суддів вказано шостий показник - компетентність та старанність. Варто сказати, що саме заключна частина документа є такою і за своїм змістом - тут міститься своєрідне підсумування всього вищевикладеного: обов'язок судді дотримуватися правил етики та етикету, постійно самовдосконалюватися, стежити за змінами в законодавстві, вимагати належної поведінки від учасників судового засідання, секретаря та помічника, суддя повинен розглядати справи справедливо і максимально швидко, не займатися певними видами діяльності, які можуть суперечити основній.

Заключна частина документа, крім визначення вживаних у ньому термінів, називається «Введення в дію» та містить таке: «3 огляду на особливості посади судді, національним судовим органам потрібно вжити ефективні заходи для створення механізмів введення в дію згаданих вище принципів, якщо такі механізми відсутні в рамках їх юрисдикції». Забігаючи наперед, слід сказати, що за мовчазної згоди Верховної Ради України рекомендації Бангалорських принципів поведінки суддів були введені в дію шляхом прийняття Радою суддів України нової редакції Кодексу суддівської етики. Загалом для законодавства нашої країни описуваний документ став свого роду інструкцією та типовим шаблоном для кодифікації нормативних етичних вимог до суддів, і натепер його роль виконана далеко не повною мірою, якщо брати до уваги ті ж соціальні опитування.

Незадовго до прийняття Бангалорських принципів поведінки суддів, у 2002 році, Консультативною радою європейських суд- 
дів було представлено до уваги Комітету Міністрів Ради Свропи висновок № 3 щодо принципів та правил, які регулюють професійну поведінку суддів, зокрема питання етики, несумісної поведінки та безсторонності. За своїм змістом цей документ є висновками та їх аргументацією щодо належної поведінки суддів. Основним його джерелом є отримані за допомогою анкетування дані про національні підходи до діяльності суддів, і вже завдяки цьому він значною мірою являє собою зріз регіонального трактування належної поведінки суддів у Свропі. Так, висновки в документі згруповані за ознакою того, на які поставлені питання дослідження вони відповідають: які стандарти поведінки повинні застосовуватися до суддів та як стандарти поведінки повинні бути сформульовані блок А; що відбувається у разі притягнення суддів до кримінальної, цивільної та дисциплінарної відповідальності - блок Б. Також у вигляді додатку документ містить відповіді на анкетні запитання, які дають можливість зрозуміти, як у конкретній державі підходять до регуляції поведінки судді.

Зробивши детальний аналіз, у змісті документа можна виявити декілька цікавих положень, що дозволяють по-новому глянути на професійну етику суддів України. Так, у п. 45 документа можна виявити вказівку на відмінність стандартів поведінки суддів від дисциплінарних чи законодавчих правил: «Вони визначають професійну здатність виконувати свої функції, зберігаючи цінності, які відповідають суспільним очікуванням, паралельно з наданими їм повноваженнями. Це є стандарти саморегулювання, які підтверджують те, що застосування закону не $є$ механічною справою, а передбачає справжні дискреційні повноваження та покладає на суддю відповідальність перед собою та перед громадянами». Таке формулювання $\epsilon$ підтвердженням того, що професійна етика суддів суттєво залежить від рефлективних можливостей конкретного судді - здатності тверезо оцінити свою відповідність займаній посаді. Тут же вживається термін «відповідальність» у контексті його відношення до суспільства та громадян - розвиток такого бачення може бути вагомим фактором теоретичних напрацювань дескриптивної професійної етики суддів.

Крім того, у п. 48 Висновків йдеться про те, на яких двох основоположних принципах повинен грунтуватися перелік професійних стандартів у поведінці суддів. Перший із них виглядає так: «перелік повинен стосуватися базових засад професійної поведінки. Він повинен визнавати, що загалом неможливо скласти повний список наперед визначених видів поведінки, які заборонено здійснювати; установлені принципи повинні бути інструментом саморегулювання для суддів, тобто визначати загальні правила, які спрямовують їхню діяльність. Крім того, незважаючи на те, що деякі з них можуть частково збігатися або доповнювати одне одного, принципи поведінки повинні діяти незалежно від дисциплінарних правил, застосовуваних до суддів, у тому сенсі, що недотримання одного 3 таких принципів не означає само по собі вчинення дисциплінарного порушення або вчинення цивільного чи кримінального правопорушення» [6]. Цей принцип, по суті, заперечує популярну в наукових колах думку про те, що етичні правила поведінки суддів повинні бути чітко визначеними та не допускати загального трактування. Неоднозначність таких етичних категорій, як справедливість, совість, добро, зло тощо, як і саме їх існування, унеможливлюють конкретизацію моральних приписів поведінки за нормативно-правовим зразком - якщо визначення будь-якого вчинку як законного чи незаконного не викликає труднощів на практиці, то рішення про справедливість чи несправедливість певних дій значною мірою залежить від суб'єкта такого оцінювання. Таким чином, у формуванні переліку правил поведінки суддів з метою забезпечення її відповідності суспільній моралі використовується така її інтерпретація, яка фактично є усередненим відображення моралі кожного окремого індивіда. Такий підхід до визначення норм професійної етики судді є вимушеним і єдино правильним. Але це не означає, що слід допускати різне за змістом визначення тих чи інших норм професійної етики суддів на користь чиїхнебудь інтересів. На думку автора, це, скоріше, говорить про необхідність створення максимально неупередженого, колегіального і різноманітного за представницьким складом колегіального органу, якому слід надати повноваження у сфері кваліфікації тих чи інших дій суддів у розумінні їх відповідності нормам суспільної моралі та наділити такий орган правом видавати роз'яснення з приводу інтерпретації тих чи інших норм суддівської етики і їх застосування на практиці. Про необхідність створення такого органу говориться в тому числі в п. 29 Висновків: «Судді повинні гідно поводити себе у своєму приватному житті. 3 огляду на різноманіття культурного життя у державах-членах Ради Свропи та постійний розвиток моральних цінностей стандарти поведінки суддів у приватному житті неможливо викласти точно. КРСС 


\section{$6 / 2019$ \\ судоУстРІй}

заохочує утворення в рамках судової системи одного чи більше органів або осіб, що виконували б консультативні й дорадчі функції та були б доступними для суддів, коли у них виникає сумнів щодо сумісності їньої приватної діяльності зі статусом судді. Наявність таких органів або осіб могла б стимулювати обговорення в межах судової влади змісту та важливості правил етики. Такі органи або особи могли б діяти під егідою Верховного Суду або об'єднань суддів. Вони у будь-якому разі повинні бути відокремленими від органів, що відповідають за застосування дисциплінарних санкцій, та мати інші цілі діяльності» [3].

Другий принцип формування правил суддівської поведінки у розумінні авторів Висновків є таким: «Принципи професійної поведінки повинні складатися самими суддями. Вони повинні бути інструментами саморегулювання, що виникають у самій судовій системі та дають можливість судовій владі отримати легітимацію, діючи в межах загальноприйнятих стандартів етики. Необхідно організувати широкі консультації, можливо, під егідою особи або органу, про який ішлося в пункті 29 та який був би також відповідальний за роз'яснення і тлумачення стандартів професійної поведінки» [3]. Здійснивши аналіз змісту цього принципу, можна зробити висновок про те, перед ким судді несуть відповідальність за недотримання етичних приписів - перед суспільством (вказівка на те, що правила професійної етики суддів повинні створюватися в межах загальноприйнятих стандартів етики), яке легітимізувало суддівську саморегуляцію (формальним автором Кодексу суддівської етики є Рада суддів України) 3 усіма наслідками, які звідси випливають. Так, фактично стає очевидним ймовірний «ланцюг» етичної відповідальності суддів: індивідуально вони несуть її перед Радою суддів України, яка в свою чергу відповідальна перед суспільством, оскільки воно дало органу суддівського самоврядування можливість саморегулювання через формальне визначення принципів професійної етики.

\section{Висновки}

Загалом значення Висновків для національного законодавства визначається як опосередковане, але від того вони не менш важливі, ніж Бангалорські принципи поведінки суддів. Так, можна помітити що деякі 3 рекомендацій Консультативної ради європейських суддів згодом після їх представлення отримали своє відображення i в національній нормативно-правовій базі, яка стосується професійної етики суддів. Крім того, даний документ цікавий з позиції можливості здійснення порівняльного аналізу, оскільки є укладеним на базі вельми інформативних даних, отриманих від більшості країн Європи.

\section{Список використаних джерел:}

1. Городовенко В. В. Проблеми становлення незалежної судової влади в Україні : монографія. Київ : Фенікс, 2007. 224 с.

2. Звіт за результатами соціологічного дослідження «Ставлення громадян України до судової системи» / Український центр економічних і політичних досліджень імені Олександра Разумкова. 2017. URL: http://rsu.gov.ua/uploads/article/finalreport-survey-e07f150174.pdf.

3. Висновок № 3 до уваги Комітету Міністрів Ради Європи щодо принципів та правил, які регулюють професійну поведінку суддів, зокрема, питання етики, несумісної поведінки та безсторонності / Консультативна рада європейських суддів. 2002. URL : https://court.gov.ua/userfiles/ visn_3_2002.pdf.

$\overline{4}$. Меліхова Ю. А. Професійна культура судді. Проблеми законності. 2008. Вип. 94. С. 176-181.

5. Овчаренко О. Порушення етичних норм як підстава відповідальності судді. Теорія і практика правознавства : електр. наук. фах. вид. Нац. ун-ту «Юрид. акад. України імені Ярослава Мудрого». 2013. Вип. 2 (4). URL : http://nauka.jur-academy. kharkov.ua/index.php?option=com_content\&task= view\&id $=535 \&$ Itemid $=220 \&$ lang $=u \overline{\mathrm{k}}$.

6. Бангалорські принципи поведінки суддів. / Організація Об'єднаних Націй. 2006. URL: https://zakon.rada.gov.ua/laws/show/995_j67.

7. Самсін І. Л. Порушення правил етики судді як дисциплінарний проступок. Вісник Верховного Суду України. 2008. № 5 (93). С. 35-38. 
В статье исследуются и анализируются тексты основных международно-правовых актов, регламентирующих деятельность судьи. Описываются международные и европейские стандарты профессиональной этики судьи и пути их имплементации в национальное законодательство. Доказыввается необходимость соблюдения судьями этических приниипов судейской деятельности как основы формирования доверия к судебной власти.

Ключевые слова: международно-правовые стандарты, судья, судебная этика, этика судьи, Бангалорские принципы, доверие к судебной власти.

The article explores and analyzes the text of the main international legal acts regulating the activity of a judge. Describes international and European standards of professional ethics of judges and ways of their implementation in national legislation. The necessity of adherence by judges to the ethical principles of judicial activity as a basis for building trust of the public to the judiciary has been proved.

Key words: international legal standards, judge, court ethics, judge ethics, Bangalore principles, trust in the judiciary. 